\title{
Vaporization Process of CaO from CaO-stabilized Zirconia Body
}

\author{
By \\ Toshiyuki SATA and Yoshihiko UCHIDA* \\ (Research Laboratory of Engineering Materials, Tokyo \\ Institute of Technology, Ookayama, Meguroku, Tokyo)
}

\section{Introduction}

When zirconia is used as high-temperature materials, the stabilization against its crystallographic transformation is required in order to prevent the large and abrupt volume change through a transition temperature. Usually, a solid solution dissolving other cations, such as $\mathrm{Ca}^{2+}$ or $\mathrm{Y}^{3+}$, is used for the stabilization. Since $\mathrm{CaO}$ is easier to vaporize than $\mathrm{ZrO}_{2}{ }^{1 \sim 14)}$, the $\mathrm{CaO}$-stabilized zirconia may become to be partly destabilized after the use for long duration at the highest temperatures. The vaporization phenomena from the CaO-stabilized zirconia has been reported by some researchers $^{15 \sim 17}$, but only Rutman et al. has studied forcussing to a behavior of $\mathrm{CaO}$. They measured a vapor pressure of $\mathrm{CaO}$ using the Knudsen cell by means of the mass spectrometric analysis, and reported that only the $\mathrm{CaO}$ component vaporized up to $2,100^{\circ} \mathrm{C}$ without vaporization of $\mathrm{ZrO}_{2}$ component.

In this investigation, the vaporization in vacuum from the $\mathrm{ZrO}_{2}-\mathrm{CaO}$ solid solution body was treated in a state of the free evaporation to simulate a practical condition. And then the diffusion coefficients of $\mathrm{Ca}$ ion affecting to the evaporation rate of $\mathrm{CaO}$ were obtained by knowing a distributions of $\mathrm{Ca}$-concentration in the body after keeping at high temperatures.

\section{Theoretical}

In the free evaporation from the body which consists of two components, one component with higher vapor pressure evaporates predominantly, and the surface concentration of its component would decrease, if a supply from the inner part of the body was defficient. Accordingly the evaporation from two components solid solution must be investigated relating to the diffusion of a component which is easier in vaporization.

Evaporation rate $v_{v}$ and diffusion rate $v_{d}$ of a component on the surface of the body can be represented as follows;

* Now with Kurosaki Yogyo Co. Ltd., Fujita, Yawataku, Kitakyushu City, Fukuoka Prefecture.

$$
\begin{aligned}
& v_{v}=\alpha c_{s} \ldots \ldots \ldots \\
& v_{d}=D\left(\frac{\partial c}{\partial x}\right)_{x=0}
\end{aligned}
$$

where $\alpha$ is an evaporation rate constant $\left(\mathrm{cm}^{\circ} \mathrm{sec}^{-1}\right)$, $c_{s}$ is a surface concentration of a vaporizing component, and $D$ is its diffusion coefficient $\left(\mathrm{cm}^{2} \cdot \mathrm{sec}^{-1}\right)$.

According to values of the evaporation rate and the diffusion rate, following three cases are to be considered;

a) In the first case where the evaporation rate is considerably smaller than the diffusion rate, a rate of weight decrease $d w / d t$ by evaporation is perfectly controlled by the evaporation rate, and in $t \geqq 0$

$$
d w / d t=\alpha c_{s}
$$

b) In the second case, where the evaporation rate is considerably larger than the diffusion rate, the surface concentration becomes to zero rapidly and $d w / d t$ is completely controlled by the diffusion rate, namely in $t>0$ and $c_{s}=0$,

$$
d w / d t=D\left(\frac{\partial c}{\partial x}\right)_{x=0}
$$

c) In the third case, where the evaporation rate nearly equals to the diffusion rate or there are no large difference between the two, a following equation may be assumed, as used in the study of the evaporation of the lead glass by Terai et al. ${ }^{18)}$,

$$
t>0, d w / d t=D\left(\frac{\partial c}{\partial x}\right)_{x=0}=\alpha c_{s} \cdots \cdots(5)
$$

In the above three cases, the distribution of concentration of a component under the surface may be expressed as follows;

a) the concentration distribution can be considered as a constant, and b) a following equation (7) for the semi-infinite medium is obtained from Fick's second law of diffusion (6) at $t=0, c=c_{0}$ and $t>0, x=0, c=0$,

$$
\begin{aligned}
& \frac{\partial c}{\partial t}=D \frac{\partial^{2} c}{\partial x^{2}} \cdots \cdots \cdots \ldots \ldots \ldots \ldots \ldots \ldots . \cdots \cdots(6) \\
& c=\frac{2 c_{0}}{\sqrt{\pi}} \int_{0}^{\frac{x}{2 \sqrt{D t}}} e^{-\xi^{2}} d \xi=c_{0} \operatorname{erf} \frac{x}{2 \sqrt{D t}} \cdots \cdots(7)
\end{aligned}
$$

where erf represents the error function. In the c) case, equation (8) is obtained, which Crank ${ }^{19}$ ) 
has given from the equation (6) in the presence of surface evaporation

$$
\begin{aligned}
& \frac{c-c_{0}}{c_{0}}=-\operatorname{erf} c \frac{x}{2 \sqrt{D t}}+\exp \left(h x+h^{2} D t\right) \\
& \cdot \operatorname{erf} c\left(\frac{x}{2 \sqrt{D t}}+h \sqrt{D t}\right) \\
& h=\alpha / D
\end{aligned}
$$

Inserting $x=0$ to the equation (8), the surface concentration $c_{s}$ is obtained as follows,

$$
c_{s}=c_{0} \exp \left(h^{2} D t\right) \operatorname{erf} c(h \sqrt{D t})
$$

\section{Experimental}

\subsection{Preparation of specimens}

Special reagent grade $\mathrm{ZrO}_{2}(99.5 \%$ purity) and $\mathrm{CaCO}_{3}(99.096)$ were used as starting materials for samples. After weighed in compositions from 5 to 25 mole of in 5 mole of $\mathrm{CaO}$ increment, they were mixed in an agate mortar for 2 hours with methanol and were calcined for 1 hour at $1,000^{\circ} \mathrm{C}$ in air. This mixture was powdered in the mortar, and each $1.2 \mathrm{~g}$ of powder was prepressed at 1.8 $\mathrm{t} / \mathrm{cm}^{2}$ in a metallic mold to a pellet of $15 \mathrm{~mm}$ in diameter. Furthermore this prepressed body was compacted isostatically at $2.66 \mathrm{t} / \mathrm{cm}^{2}$ in a rubber mold. The green body was sintered in a vacuum $\left(1 \times 10^{-4} \mathrm{mmHg}\right)$ of a tungsten furnace at $2,100^{\circ} \mathrm{C}$ for 1 hour. Temperature measurement was made by an optical pyrometer of Hokushin Electric Works. Weight decrease after the sintering process is given in Table 1.

Table 1. Specimens sintered at $2,100^{\circ} \mathrm{C}$ for 1 hour in vacuum.

\begin{tabular}{ccccl}
\hline $\begin{array}{c}\text { Composition } \\
(\text { mole } \%) \\
\mathrm{CaO}-\mathrm{ZrO}_{2}\end{array}$ & $\begin{array}{c}\text { Weight } \\
\text { decrease } \\
(\%)\end{array}$ & $\begin{array}{c}\text { Bulk } \\
\text { density } \\
\left(\mathrm{g} / \mathrm{cm}^{3}\right)\end{array}$ & $\begin{array}{c}\text { Density } \\
(\%)\end{array}$ & Phases present \\
\hline $5 \sim 95$ & 3.15 & 5.52 & 93.5 & Monoclinic + Cubic \\
$10 \sim 90$ & 3.06 & 5.34 & 92.7 & Cubic \\
$15 \sim 85$ & 3.52 & 5.10 & 91.7 & Cubic \\
$20 \sim 80$ & 3.46 & 4.97 & 92.5 & Cubic \\
$25 \sim 75$ & 3.07 & 4.77 & - & Cubic $+\mathrm{CaZrO}_{3}$ \\
\hline
\end{tabular}

This sintered pellet was machined about $0.5 \mathrm{~mm}$ in thickness from the surfaces by a diamond grinding instrument, and a parallelism between both cross sectional surfaces was obtained within $2 \mu$ by this precise grinding. Results of the density measurements and the $\mathrm{X}$-ray examinations are given in Table 1. These densities were calculated assuming that oxygen anion vacancies were produced in equal numbers to dissolved $\mathrm{Ca}$ atoms ${ }^{20,21)}$. Fig. 1 shows the microstructure of the surface after etching with a solution of $\mathrm{HNO}_{3}-\mathrm{HCI}-\mathrm{HF}$ (3-6-4), where black spots are pores, white grains are solid solution, and gray grains are $\mathrm{CaZrO}_{3}$.

\subsection{Measurement of the evaporation rate}

Evaporation temperatures were three levels of $1,900^{\circ}, 2,000^{\circ}$ and $2,100^{\circ} \mathrm{C}$, and heating times were $5,10,15,30$ and 60 minutes. Weight changes were

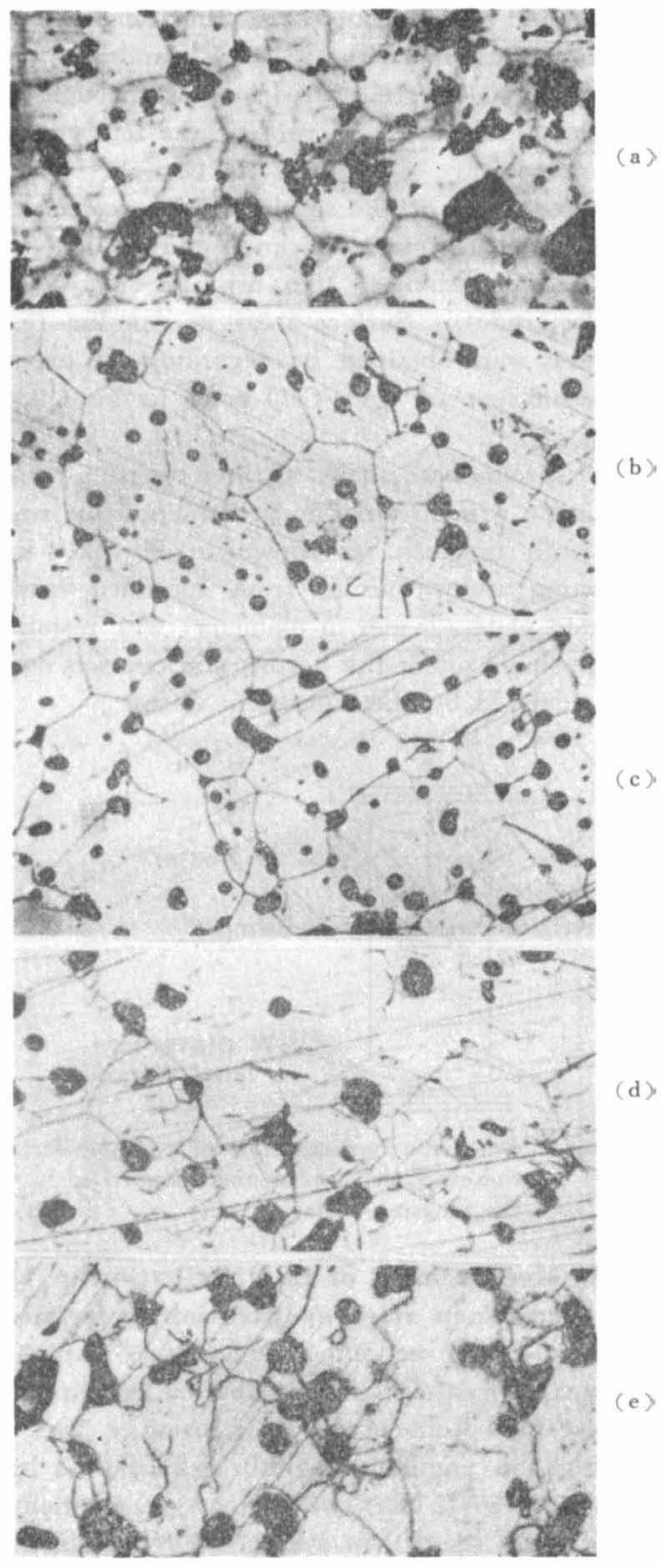

Fig. 1 Microstructure of specimens containing $5 \%$ (a), $10 \%$ (b), $15 \%$ (c), 20\% (d) and 25\% (e) of $\mathrm{CaO}$ in mole $\%(\times 220)$.

measured by a chemical balance after each evaporation run.

Evaporation experiments were carried out in vacuum $\left(7 \times 10^{-5} \mathrm{mmHg}\right)$ with the furnace ${ }^{22}$ equipped with a tungsten circular heater $(20 \mathrm{~mm} \phi, 140$ $\mathrm{mm}$ long), on which a rectangular slit $(3 \times 40 \mathrm{~mm})$ was cut off for an observation of specimen and a temperature measurement by the optical pyrometer. For accurate temperature measurement of a specimen, the optical pyrometer, an wattmeter and a thermocouple of W $5 \% \mathrm{Re} / \mathrm{W} 26 \%$ Re were used at the same time. For calibrations of these 
meters and thermocouples, melting temperatures of pure platinum wire (99.999\%) and rhodium wire $(99.9 \%)$. were measured looking through the slit described above. Errors of the temperature measurement are $\pm 10^{\circ} \mathrm{C}$ at $2,000^{\circ} \mathrm{C}$.

Surface areas of the specimens were calculated by measurements ' of the thickness and the diameter with the precision of $10 \mu$ using a micrometer (JIS-lst grade). Surface areas at running temperatures were obtained by regarding the expansion coefficient of $\mathrm{ZrO}_{2}-\mathrm{CaO}$ body to be $1.23 \times$ $10^{-50} \mathrm{C}^{-123)}$.

The specimen was held on three tungsten points of $0.3 \mathrm{~mm}$ wire in order to prevent possible reactions with tungsten, as shown in Fig. 2. For inspecting vapor species from specimen, small tungsten plate $(25 \mathrm{~mm}$ in diameter) was installed on the shield under the heater, and deposits on it were analysed by the fluorescent X-ray.

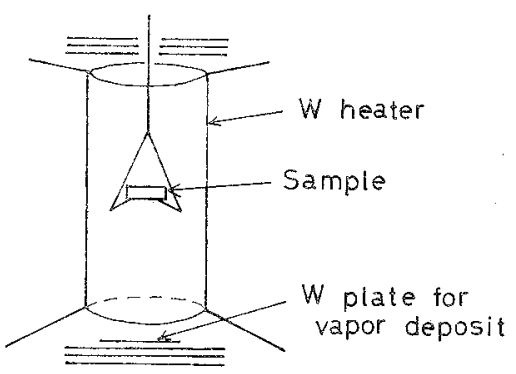

Fig. 2 Schematic representation of a sample for the evaporation experiment suspended in the tungsten heater.

\subsection{Neasurement of Ca-distribution in the specimen after evaporation experiment}

The so-called sectioning method was used for the measurement of the distribution of $\mathrm{Ca}$. A heat-treated specimen was fixed using a wax as keeping the parallelism within $\pm 2 \mu$ on an iron plate $(20 \times 20 \times 5 \mathrm{~mm})$ which has a parallelism within $4 \mu$. And then every $7 \sim 8 \mu$ in thickness were ground off by a diamond wheel of the precise surface grinder for the measurement of $\mathrm{CaO}$ content on every cross section.

$\mathrm{Ca}-$ concentration on a surface of the every section was analysed quantitatively by the fluorescent $\mathrm{X}$-ray apparatus (Rigaku Denki GF-S type) at 20 $\mathrm{kV}$ and $20 \mathrm{~mA}$. EDDT was used as the diffraction crystal. The $\mathrm{X}$-ray beam was irradiated on a circle area of $10 \mathrm{~mm}$ in diameter masked by aluminium holder, and the $\mathrm{X}$-ray $\mathrm{Ca} \mathrm{K} \alpha_{1}$ emitted was measured by means of the constant time calculation method for 20 seconds. Ca-content was obtained by the calibration curve which was constructed from the standard specimens of $\mathrm{ZrO}_{2}-\mathrm{CaO}$ solid solution containing known contents of $\mathrm{CaO}$. Since the penetration distance of $\mathrm{Ca} \mathrm{K} \alpha_{1}$ into
$\mathrm{ZrO}_{2}$ is calculated to be an half value thickness less than $1.4 \mu$, it is considered that the concentra. tions of the cross sectional surfaces were obtained with sufficient precision.

\section{Results}

\subsection{Vapor species}

Results of the analysis of vapor deposit on the tungsten plate from the specimen is that $\mathrm{Ca}$ was detected from the experiment at $1,900^{\circ}, 2,000^{\circ}$ and $2,100^{\circ} \mathrm{C}$ and a very small amount of $\mathrm{Zr}$ at $2,100^{\circ} \mathrm{C}$ only.

\subsection{Evaporation rates}

Figs. 3,4 and 5 indicate the weight change of specimens containing $5 \sim 25$ mole $\%$ of $\mathrm{CaO}$ at

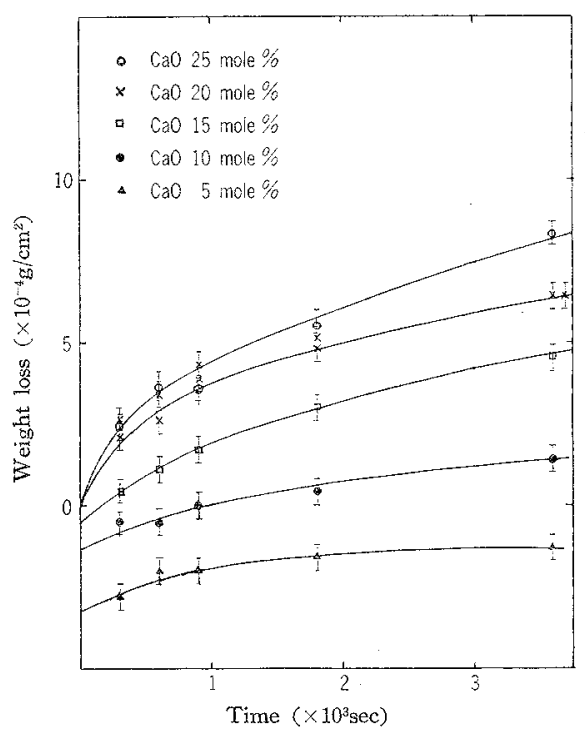

Fig. 3 Weight loss vs. time at $1,900^{\circ} \mathrm{C}$.

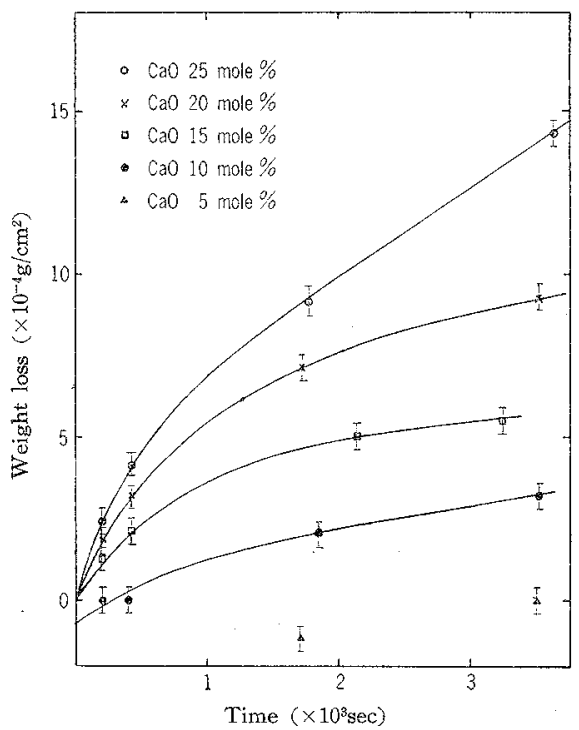

Fig. 4 Weight loss vs. time at $2,000^{\circ} \mathrm{C}$. 


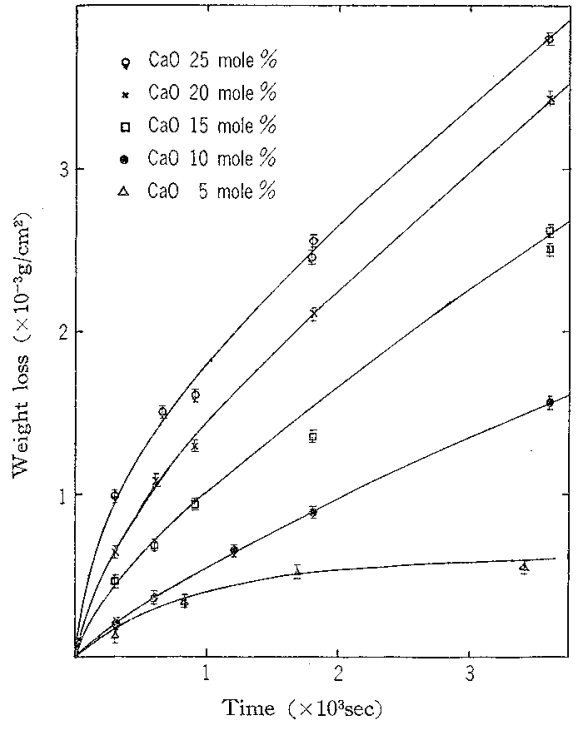

Fig. 5 Weight loss vs. time at $2,100^{\circ} \mathrm{C}$.

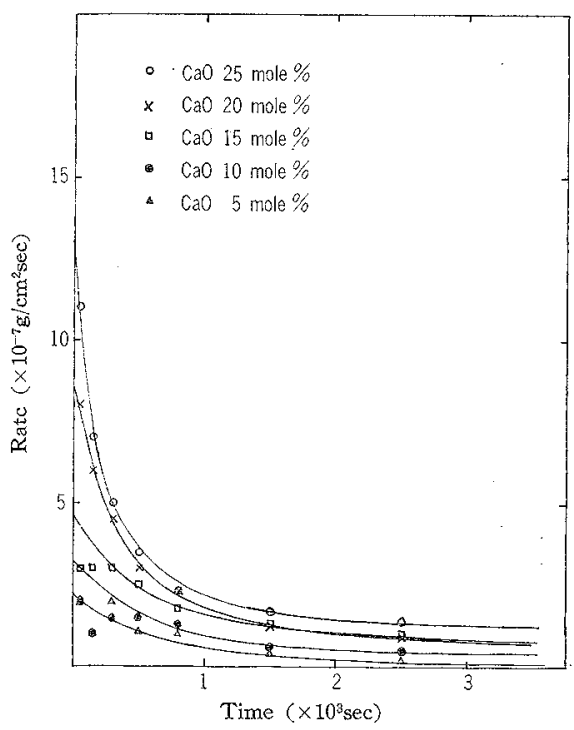

Fig. 6 Weight loss rate vs. time at $1,900^{\circ} \mathrm{C}$.

$1,900^{\circ}, 2,000^{\circ}$ and $2,100^{\circ} \mathrm{C}$ with time. Weight decreases are larger with the increasing $\mathrm{CaO}$ contents and are steep in an initial stage. Figs. 6, 7 and 8 give the weight-loss rate (same as evaporation rate) calculated from Figs. 3, 4 and 5 respectively. Figs. 9, 10 and 11 show the change of $\mathrm{CaO}$ content in the original surface at each temperature. It is shown that the evaporation rate and the surface concentration of $\mathrm{CaO}$ similarly decrease steeply at an early time.

\subsection{Apparent diffusion coefificient}

From the data of the weight-loss rate and the surface concentration described above, it is evident that this evaporation process corresponds to the third case (c) mentioned at the paragraph 2.

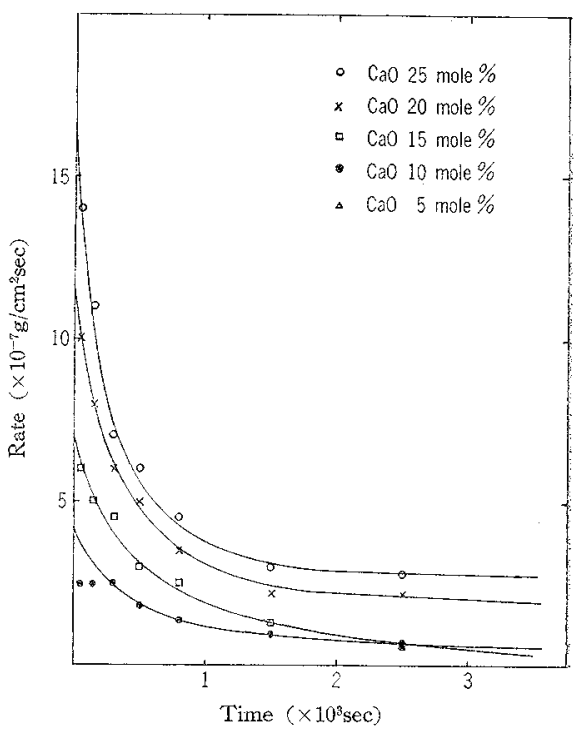

Fig. 7 Weight loss rate vs. time at $2,000^{\circ} \mathrm{C}$.

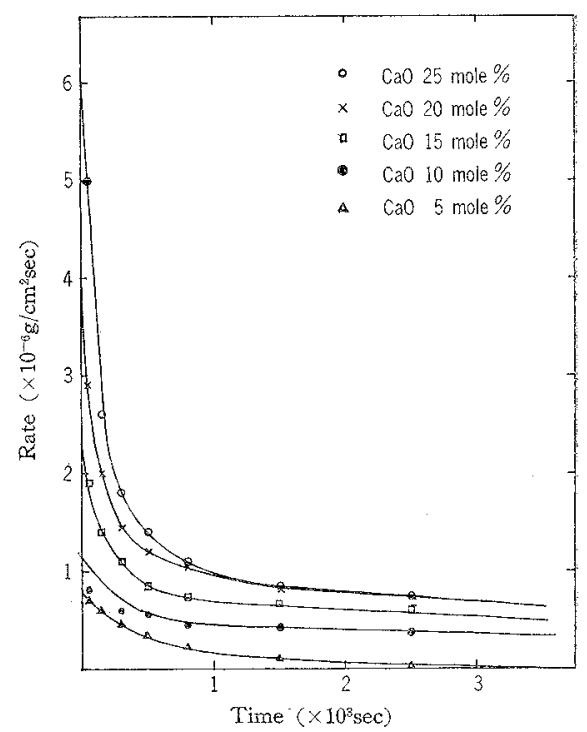

Fig. 8 Weight loss rate vs. time at $2,100^{\circ} \mathrm{C}$.

Figs. 12, 13 and 14 show several examples of distribution of $\mathrm{Ca}$-content at $1,900^{\circ}, 2,000^{\circ}$ and $2,100^{\circ} \mathrm{C}$ and in $420,1,710$ and 3,510 seconds for the specimen of 20 mole $\%$ of $\mathrm{CaO}$.

Apparent diffusion coefficients were calculated. from these results by applying the equation (8). For this, since the surface concentration $c_{s}$ are known, $h^{2} D t$ can be obcained from the equation (10). From the equation (9), a relationship of $\alpha$ to $D$ are given in each evaporation time $t$. Using the equation (8), distribution curves of $c$ at various depths $x$ are calculated for some assumed values of various diffusion coefficients $D$ in constant $t$, as given in Fig. 15 as an example. Comparing these concentration curves with the observed 


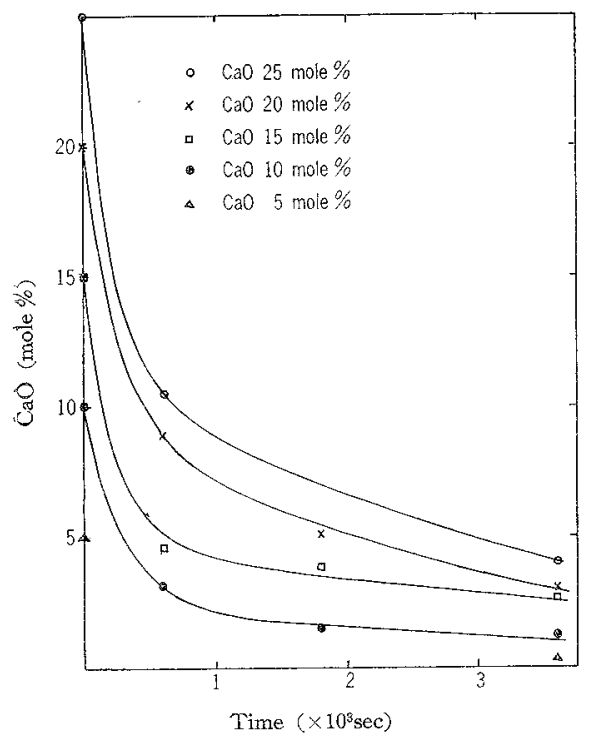

Fig. 9 Variation in contents of $\mathrm{CaO}$ in the surface with time at $1,900^{\circ} \mathrm{C}$.

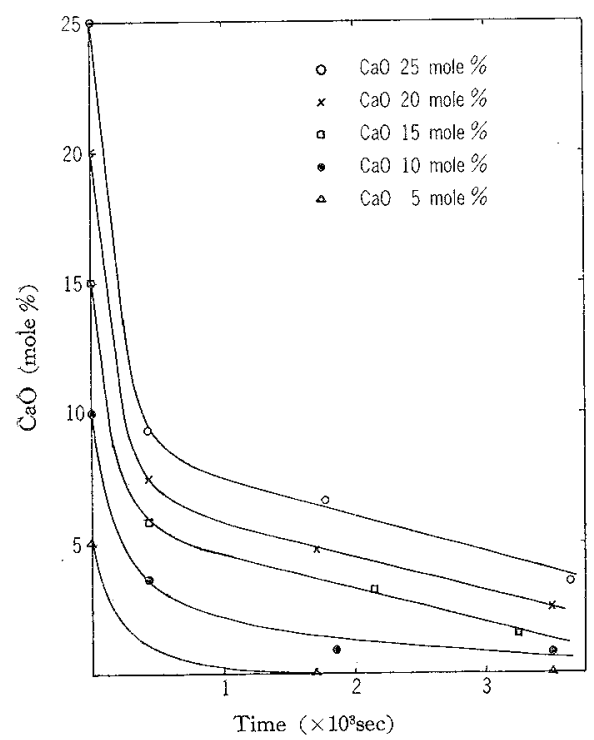

Fig. 10 Variation in contents of $\mathrm{CaO}$ in the surface with time at $2,000^{\circ} \mathrm{C}$.

curves, the most precise value of diffusion constant was chosen. Figs. 16, 17 and 18 show plots of the diffusion coefficients thus obtained as a function of $\mathrm{CaO}$ content at the initial time. From these relations it was concluded that the diffusion coefficients vary in exponential functions of $\mathrm{CaO}$ concentration, as expressed by

$$
D=D_{0} \exp k c
$$

Next, assuming this exponential function and using Crank's iterative method $^{19)}$, the more precise concentration distribution well fitted to the measured values were obtained, as given in Fig. 19 as an example. Comparisons of calculated

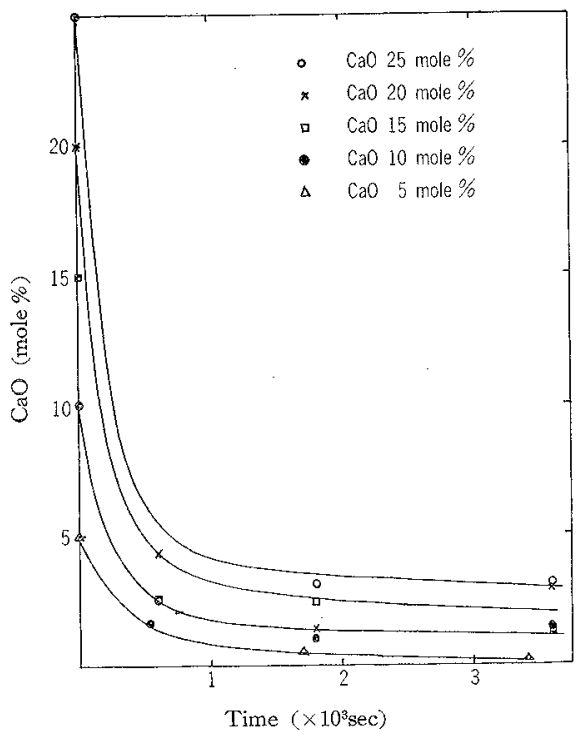

Fig. 11 Variation in contents of $\mathrm{CaO}$ in the surface with time at $2,100^{\circ} \mathrm{C}$.

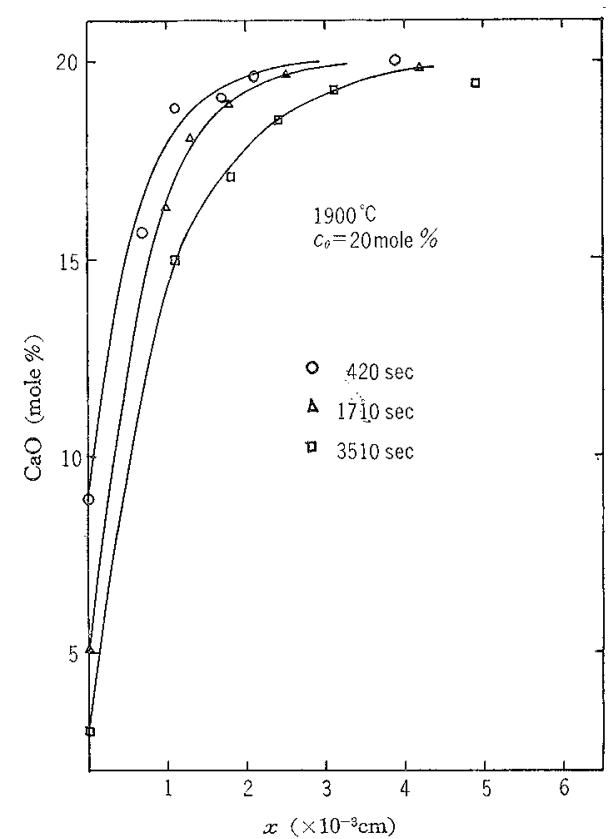

Fig. $12 \mathrm{CaO}$-concentration distributions of the specimen $(20$ mole $\%$ ) in the surface at 3 levels of times at $1,900^{\circ} \mathrm{C}$.

value of concentration distribution with that of the observed distribution lead to the following functions at each temperature, at $1,900^{\circ} \mathrm{C}$

$$
D_{\mathrm{Ca}}=0.7 \times 10^{-10} \exp 0.10 c
$$

at $2,000^{\circ} \mathrm{C}$

$$
D_{\mathrm{Ca}}=1.3 \times 10^{-10} \exp 0.098
$$

at $2,100^{\circ} \mathrm{C}$

$$
D_{\mathrm{Ca}}=3.5 \times 10^{-10} \exp 0.092
$$




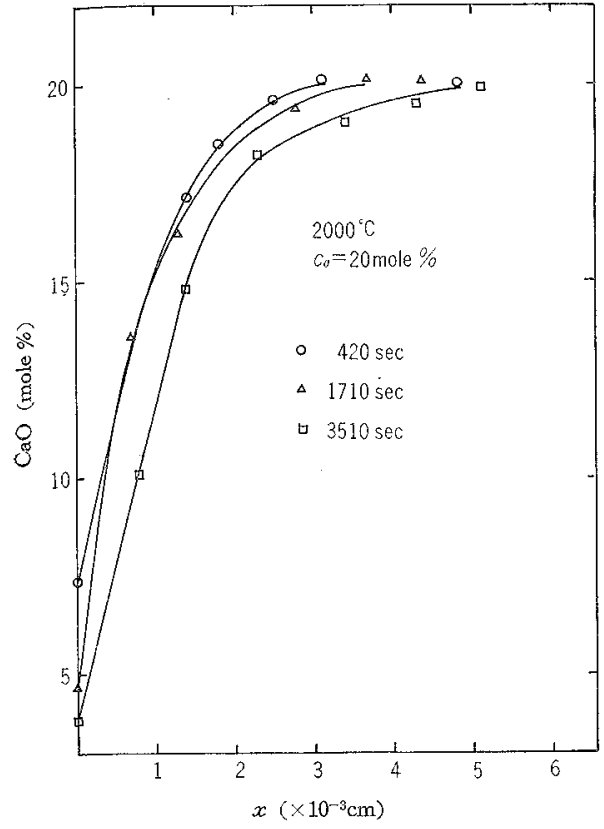

Fig. $13 \mathrm{CaO}$-concentration distributions in the surface of the specimen (20 mole \% $\mathrm{CaO})$ at 3 levels of times at $2,000^{\circ} \mathrm{C}$.

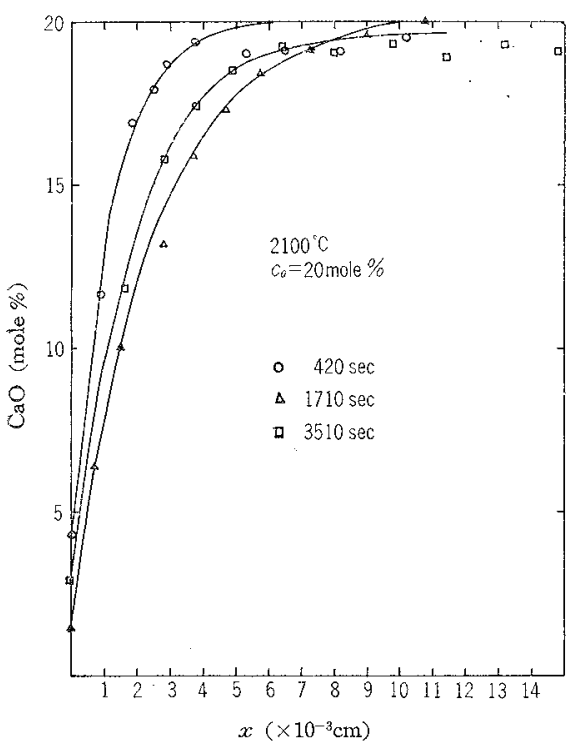

Fig. 14 CaO-concentration distributions in the surface of the specimen (20 mole\% $\mathrm{CaO})$ at 3 levels of times at $2,100^{\circ} \mathrm{C}$.

These functions are indicated as real linear lines in the Figs. 16, 17 and 18.

Plotting the apparent diffusion coefficents obtained at an each concentration using the equations (12), (13) and (14) against reciprocal absolute temperatures, their least square fits are given as Fig. 20. According to this, the each relation of $D$ with temperatures represents the following

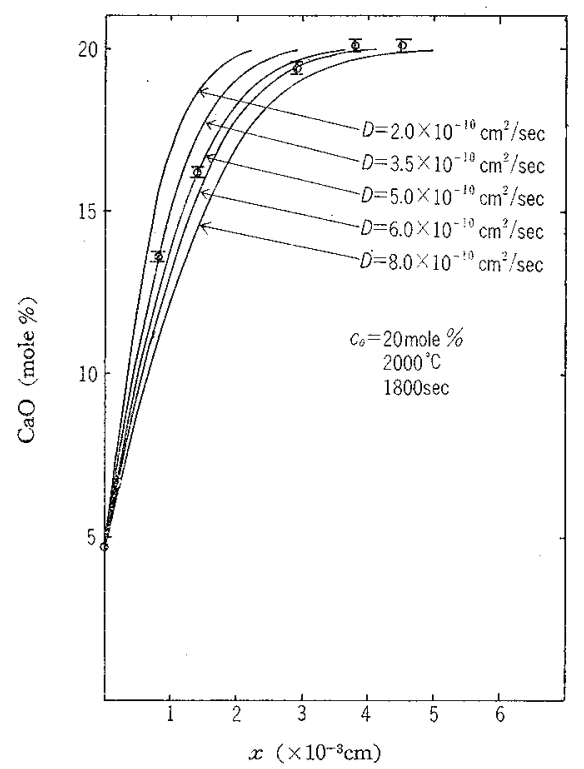

Fig. 15 Plots of $\mathrm{CaO}-$ concentration vs. distances from the surface, and a calculated curves using the equation (8).

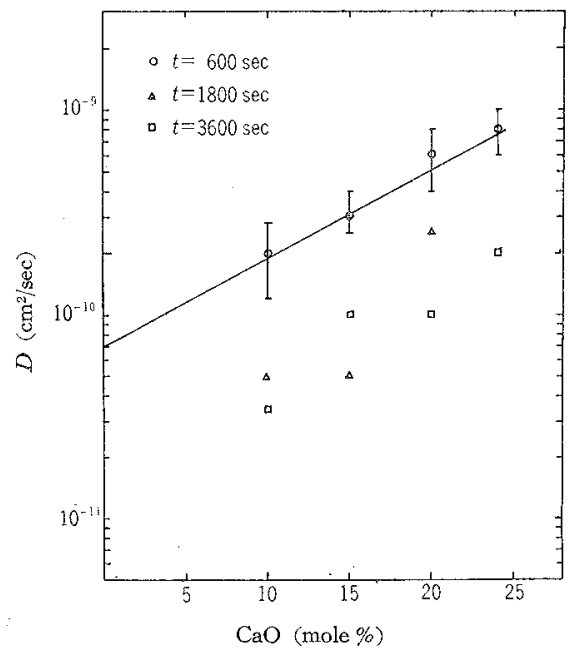

Fig. 16 Diffusion coefficients of $\mathrm{Ca}$ ion $\mathrm{vs}, \mathrm{CaO}$ contents at $1,900^{\circ} \mathrm{C}$.

equations (17) to (21).

$$
\begin{aligned}
& \mathrm{CaO} 5 \text { mole } \% \\
& D_{\mathrm{Ca}}=0.0101 \exp (-79,300 / R T)
\end{aligned}
$$

$\mathrm{CaO} 10$ mole $\%$

$$
D_{\mathrm{Ca}}=0.0114 \exp (-77,800 / R T)
$$

$\mathrm{CaO} 15$ mole $\%$

$$
D_{\mathrm{Ca}}=0.0133 \exp (-76,800 / R T)
$$

$\mathrm{CaO} 20$ mole $\%$

$$
D_{\mathrm{Ca}}=0.0122 \exp (-73,800 / R T)
$$

$\mathrm{CaO} 25$ mole $\%$

$$
D_{\mathrm{Ca}}=0.0109 \exp (-70,900 / R T)
$$

Values of activation energy have units of cal/mole. Evaporation rate constants are given in Table 2. 


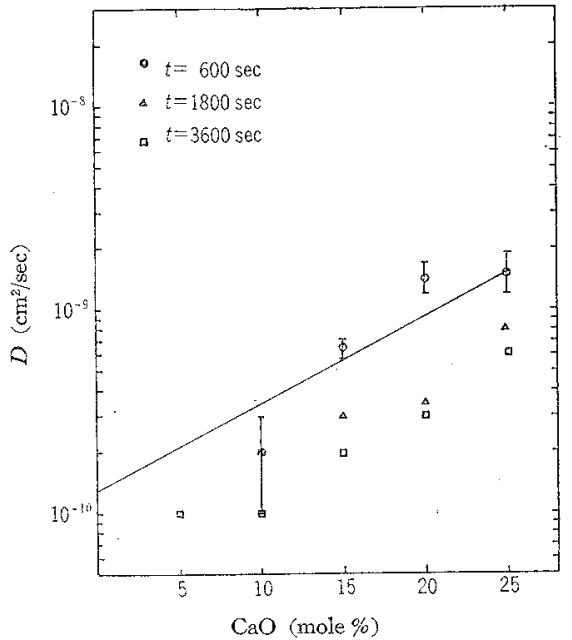

Fig. 17 Diffusion coefficients of $\mathrm{Ca}$ ion vs. $\mathrm{CaO}$ contents at $2,000^{\circ} \mathrm{C}$.

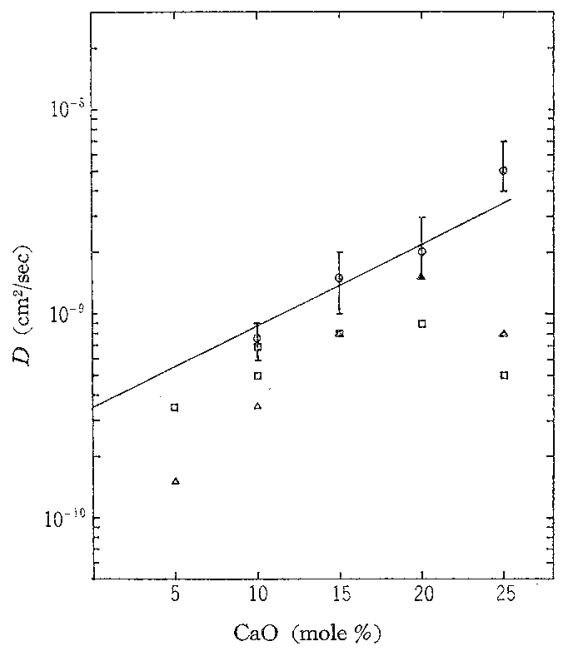

Fig. 18 Diffusion coefficients of $\mathrm{Ca}$ ion vs. $\mathrm{CaO}$ contents at $2,100^{\circ} \mathrm{C}$.

Table 2. Evaporation rate constants.

\begin{tabular}{|c|c|c|c|c|}
\hline \multirow{2}{*}{$\begin{array}{c}\text { Initial } \\
\text { concentration } \\
\text { of CaO } \\
\text { (mole \%) }\end{array}$} & \multirow{2}{*}{$\begin{array}{l}\text { Time } \\
-(\mathrm{sec})\end{array}$} & \multicolumn{3}{|c|}{$\begin{array}{l}\text { Evaporation rate constant } \\
\alpha(\mathrm{cm} / \mathrm{sec})\end{array}$} \\
\hline & & $1,900^{\circ} \mathrm{C}$ & $2,000^{\circ} \mathrm{C}$ & $2,100^{\circ} \mathrm{C}$ \\
\hline \multirow{3}{*}{5} & 600 & - & - & - \\
\hline & 1,800 & - & - & $2.01 \times 10^{-6}$ \\
\hline & 3,600 & $5.00 \times 10^{-7}$ & - & $4.05 \times 10^{-6}$ \\
\hline \multirow{3}{*}{10} & 600 & $9.13 \times 10^{-7}$ & $7.44 \times 10^{-7}$ & $4.05 \times 10^{-6}$ \\
\hline & 1,800 & $6.05 \times 10^{-7}$ & $2.26 \times 10^{-6}$ & $2.45 \times 10^{-6}$ \\
\hline & 3,600 & $4.23 \times 10^{-7}$ & $1.65 \times 10^{-6}$ & $1.68 \times 10^{-6}$ \\
\hline \multirow{3}{*}{15} & 600 & $1.13 \times 10^{-5}$ & $9.48 \times 10^{-7}$ & $4.91 \times 10^{-6}$ \\
\hline & 1,800 & $3.37 \times 10^{-7}$ & $1.01 \times 10^{-6}$ & $2.25 \times 10^{-6}$ \\
\hline & 3,600 & $5.17 \times 10^{-7}$ & $1.31 \times 10^{-6}$ & $3.73 \times 10^{-6}$ \\
\hline \multirow{3}{*}{20} & 600 & $8.59 \times 10^{-7}$ & $1.90 \times 10^{-6}$ & $4.50 \times 10^{-6}$ \\
\hline & 1,800 & $7.45 \times 10^{-7}$ & $9.60 \times 10^{-7}$ & $7.48 \times 10^{-6}$ \\
\hline & 3,600 & $6.05 \times 10^{-7}$ & $8.11 \times 10^{-7}$ & $1.88 \times 10^{-5}$ \\
\hline \multirow{3}{*}{25} & 600 & $1.19 \times 10^{-6}$ & $1.95 \times 10^{-6}$ & $1.44 \times 10^{-5}$ \\
\hline & 1,800 & - & $1.23 \times 10^{-6}$ & $2.99 \times 10^{-6}$ \\
\hline & 3,600 & $7.98 \times 10^{-7}$ & $1.58 \times 10^{-6}$ & $1.49 \times 10^{-6}$ \\
\hline
\end{tabular}

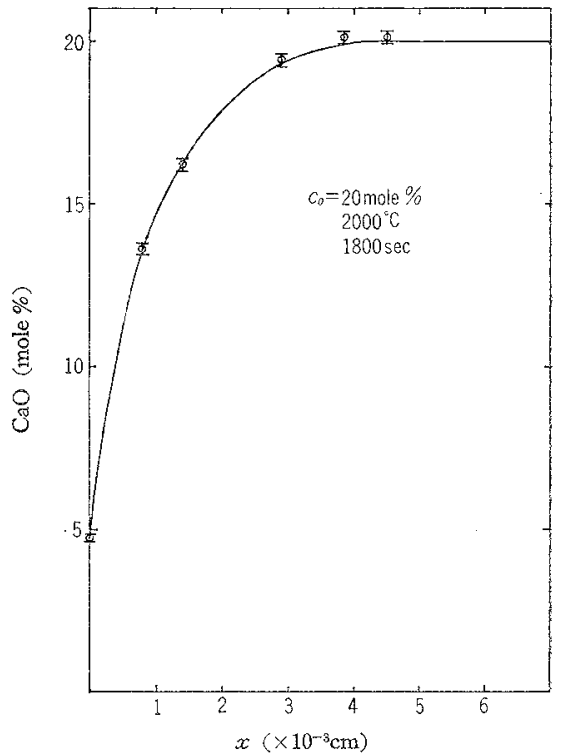

Fig. 19 Agreement of a calculated curve obtained using Crank's iterative method with the plots of measured values.

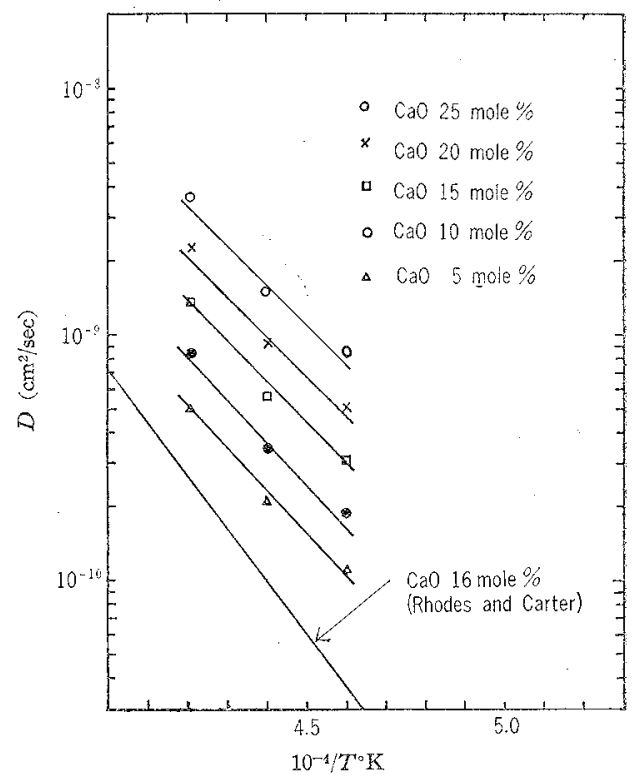

Fig. 20 Diffusion coefficients of $\mathrm{Ca}$ ion vs. the reciprocal absolute temperatures.

\section{Disergsion}

Vaporization deposit from the $\mathrm{ZrO}_{2}-\mathrm{CaO}$ body up to $2,100^{\circ} \mathrm{C}$ was almost $\mathrm{CaO}$, so a following reaction may occur, the same as the report of Rutman et $\mathrm{al}^{177}$.,

$$
\begin{aligned}
& y \mathrm{ZrO}_{2-x} . x \mathrm{CaO} \rightarrow y \mathrm{ZrO}_{2-x^{\prime}}+x \mathrm{Ca} \\
& \quad+\frac{x}{2} \mathrm{O}_{2} \ldots \ldots \ldots \ldots \ldots \ldots \ldots \ldots \ldots \ldots \ldots \ldots \ldots \ldots \ldots \ldots \ldots \ldots \ldots
\end{aligned}
$$

This equation was conducted from an assumption that the oxygen anion vacancies were produced 
by equal numbers to $\mathrm{CaO}$ dissolved in the solid solution ${ }^{20\} \sim 22)}$.

From the above results, the weight loss on heating is due to the evaporation of $\mathrm{CaO}$. But there were some results of weight increase at $t=$ 0 for the specimens $(<15$ mole $\% \mathrm{CaO}$ at 1,900 ${ }^{\circ} \mathrm{C}$ and $<10$ mole $\% \mathrm{CaO}$ at $2,000^{\circ} \mathrm{C}$ ). These results suggest that the another reaction may occur, for instance, an absorption of oxygen. Pure $\mathrm{ZrO}_{2}$ leads to a non-stoichiometric composition $\left(\mathrm{ZrO}_{1.96}{ }^{24)}\right)$ by losing some oxygen atoms in vacuum at a high temperature, and may have equilibrium oxygen contents at different temperatures. If a specimen sintered at $2,100^{\circ} \mathrm{C}$ was heated at a lower temperature (for instance 1,900 ${ }^{\circ} \mathrm{C}$ ), it would increase in weight by oxygen absorption. It is understandable from the above that the weight increase was larger with the lower content of $\mathrm{CaO}$ due to their structure near that of the pure $\mathrm{ZrO}_{2}$.

From the above evaporation experiments for the two-component solid solution by the Langmuir free evaporation, it was difficult to obtain the vapor pressure of the solid solutions containing a known $\mathrm{Ca}$ content on the surface due to the variation of $\mathrm{Ca}$ content with time and the uncertainty of the vaporization coefficient of $\mathrm{CaO}$. The authors are expecting the reexamination for the vapor pressure of $\mathrm{Ca}$ by the equilibrium method using the Knudsen effusion cell.

As shown in Fig. 20 the apparent diffusion coefficients obtained in this report can be compared with the value of the self diffusion coefficient by Rhodes et al. ${ }^{25}$ obtained using $\mathrm{Ca}$ isotope. For example, $D$ in the solid solution containing 15 mole $\%$ of $\mathrm{CaO}$ is $5.4 \sim 8.4$ times larger and their activation energy is $0.7 \sim 0.8$ times smaller than that of Rhodes et al.. This difference may be due to the effect of grain boundary diffusion and the pore surface diffusion which occured in poly. crystalline solids with somewhat smaller density, due to some structure change (expansion of crystal lattice, etc) by large concentration gradient of $\mathrm{CaO}$, due to the limitation of applicability of the theory and so on. As given in Fig. 1, grains of zirconia are larger and therefore the grain boundary is shorter with the increasing $\mathrm{CaO}$ content. So it is sure that the diffusion coefficient has a larger variation having the exponential one of concentration:

With the solid solubility of $\mathrm{CaO}$ to $\mathrm{ZrO}_{2}$, an equal number of anion vacancies forms and then the lattice size expands. Crystal structure tends to a loose packing and the bond strength of the lattice weakens. For these reasons, the apparent activation energy of diffusion lowered, and the diffusion coefficient varied exponentially with $\mathrm{CaO}$ content. From these discussions, the apparent diffusion coefficients may be expressed as a function of concentration and temperature as follows,

$$
\begin{aligned}
D_{\mathrm{Ca}}= & 0.0116 \exp \\
& {[-(82,100-440 \mathrm{c}) / R T] \mathrm{cm}^{2} \cdot \mathrm{sec}^{-1} }
\end{aligned}
$$

\section{Summary}

Free evaporation experiments for the solid solution of $\mathrm{ZrO}_{2}-\mathrm{CaO}(5 \sim 25$ mole $\% \mathrm{CaO})$ were carried out in vacuum at $1,900^{\circ}, 2,000^{\circ}$ and 2,100 ${ }^{\circ} \mathrm{C}$. $\mathrm{CaO}$ predominantly vaporized at these temperatures, and it was confirmed that the evaporation rate was controlled by the diffusion of $\mathrm{Ca}$ ions in the surface layer of the solid solution body. Apparent diffusion coefficients were calculated from the $\mathrm{Ca}$ content distribution which were measured by means of the fluorescent X-ray analysis for sectional faces. The diffusion coefficient increases as an exponential function with $\mathrm{CaO}$ content in the solid solution, and the activation energy decreases linearly with $\mathrm{CaO}$ contents because of a structure weakening with $\mathrm{CaO}$ content. The apparent diffusion coefficient of $\mathrm{Ca}$ ion in the evaporation process is expressed by a following equation

$$
\begin{aligned}
D_{\mathrm{Ca}}= & 0.0116 \exp \\
& {[-(82,100-440 \mathrm{c}) / R T] \mathrm{cm}^{2} \cdot \mathrm{sec}^{-1} }
\end{aligned}
$$

where $c$ is mole $\%$ of $\mathrm{CaO}$.

\section{References}

1) A. Claassen and C.F. Veenemans, Z. Physik 80, 342 (1933).

2) L. Brewer and R.F. Porter, J. Chem. Phys. 22, 1867 (1954).

3) I. Pelchovitch, Philips Res. Repts. 9, 42 (1954).

4) C.A. Alexender, J.S. Ogden and A. Levy, J. Chem. Phys. 39, 3057 (1963).

5) T.P.J.H. Babeliowsky, J. Chem. Phys. 38, 2035 (1963).

6) J. Drowart, G. Exsteen and G. Verhegen, Trans. Faraday Soc. 60, 1920 (1964).

7) R.L. Altman, J. Phys. Chem. 67, 366 (1963).

8) M.G. Inghram, W.A. Chupka and J. Berkowitz, J. Chem. Phys. 27, 569 (1957).

9) W.A. Chupka and M.G. Inghram, J. Chem. Phys. 26, 1207 (1957).

10) J. Berkowitz and W.A. Chupka and M.G. Inghram, J. Phys. Chem. 61, 1569 (1957).

11) P.W. Gilles, Ann. Rev. Phys. Chem. 12, 355 (1961).

12) M.M. Nakata, U.S. Atomic Energy Comm. NAASR-6095 10 (1961).

13) E.G. Wolff and C.B. Alcock, Trans. Brit. Ceram. Soc. 61, 667 (1962).

14) S.A. Shckukarev, Akad. Nauk SSSR sb Statei 208 (1965).

15) K. Mark Bonar, J.L. Canningham and F.H. Walther, Am. Ceram. Soc. Bull. 46, 683 (1967).

16) E.S. Lukin and D.N. Poluboyarinov, Ogneupory 
29, 418 (1968).

17) D.S. Rutman, I.L. Chemnikoba, T.S. Ignatoba and G.A. Semenob, Ogneupory 33, 49 (1968).

18) R. Terai and C. Ueno, Yogyo-kyokai-shi 74, 283 (1966).

19) J. Crank, "Mathematics of Diffusion", Oxford Univ. Press., New York (1956) pp. 34 and 149.

20) F. Hund, Z. Physik. Chem. 199, 142 (1952).

21) T.Y. Tien and E.C. Subbarao, J. Chem. Phys. 39, 1041 (1963).

22) T. Sata, Rev. Int. Hautes, Tempér. et Réfract. 3, 337 (1966).
23) T.W. Smoot and J.R. Ryan, J. Am. Ceram. Soc. 46, 597 (1963).

24) R.J. Ackermann, P.W. Gilles and R.J. Thorn, J. Am. Chem. Soc. 78, 1967 (1956).

25) W.H. Rhodes and R.E. Carter, J. Am. Ceram. Soc. 49, 244 (1966).

26) R.A. Swalin, "Thermodynamics of Solid", John Willey \& Sons, Inc., New York (1962).

27) P.G. Shewmon, "Diffusion in solid", McGraw-Hill Book Co. New York.

[Received July 4, 1970]

\title{
$\mathrm{CaO}$ 安定化ジルコニアからの CaO の高温蒸発過程
}

\author{
佐多敏之。内田良彦 \\ (東京工業大学, 工業材料研究所)
}

ジルコニア材料を高温で使用するとき, $\mathrm{CaO}$ が表面 から選択的俚蒸発して不安定化され，表面伦応力を生 じる、これを明らかにする目的で， $\mathrm{ZrO}_{2}-\mathrm{CaO}(5 \sim 25$ mole \%) 2 成分系焼結体 $\left(2,100^{\circ} \mathrm{C}\right)$ をタングステン炉 の $1,900^{\circ} \sim 2,100^{\circ} \mathrm{C}$ で $7 \times 10^{-5} \mathrm{mmHg}$ の真空中で加熱 し, $\mathrm{CaO}$ の蒸発 $\left(\mathrm{ZrO}_{2}\right.$ 汇 $2,100^{\circ} \mathrm{C}$ で僅办蒸発) を自 由蒸発法で測定した。蒸発による重量減少速度法最初の 20 分で急激に低下してゅるやかになる。したがってこ の方法では䓠気圧を正確に求めることはできなかった。
蒸発後の試料を研摩しながら, 表面の $\mathrm{Ca}$ 紗光X線分 析により測定して濃度分布を求好た。表面の Ca 濃度は

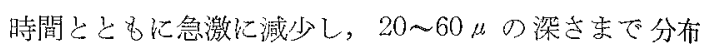
が生ずる。蒸発速度は早く，それが内部から表面への Ca の搪散速度に律速されることが判ったので，この濃 度分布加ら Ca の拡散保数省各初期濃度について求为

$$
\begin{aligned}
D_{\mathrm{Ca}}= & 0.0116 \exp \\
& {[-(82,100-440 \mathrm{c}) / R T] \mathrm{cm}^{2} \cdot \mathrm{sec}^{-1} }
\end{aligned}
$$

を得た。 $c$ は $\mathrm{CaO}$ の mole\%で岁る。 